\title{
Zinc-Nickel Codeposition in Sulfate Solution Combined Effect of Cadmium and Boric Acid
}

\author{
Y. Addi and A. Khouider \\ Faculté de Chimie, USTHB, BP 09, Bab Ezzouar, Alger 16111, Algeria \\ Correspondence should be addressed to Y. Addi, addi_yassine@yahoo.fr \\ Received 18 February 2011; Revised 26 June 2011; Accepted 12 July 2011 \\ Academic Editor: José H. Zagal
}

Copyright (๑) 2011 Y. Addi and A. Khouider. This is an open access article distributed under the Creative Commons Attribution License, which permits unrestricted use, distribution, and reproduction in any medium, provided the original work is properly cited.

\begin{abstract}
The combined effect of cadmium and boric acid on the electrodeposition of zinc-nickel from a sulfate has been investigated. The presence of cadmium ion decreases zinc in the deposit. In solution, cadmium inhibits the zinc ion deposition and suppresses it when deposition potential value is more negative than $-1.2 \mathrm{~V}$. Low concentration of $\mathrm{CdSO}_{4}$ reduces the anomalous nature of $\mathrm{Zn}$ $\mathrm{Ni}$ deposit. Boric acid decreases current density and shifts potential discharge of nickel and hydrogen to more negative potential. The combination of boric acid and cadmium increases the percentage of nickel in the deposit. Boric acid and cadmium.
\end{abstract}

\section{Introduction}

Great interest has been shown in the possibilities offered by the electrodeposition of alloys, particularly in the automotive industry. It is well known that alloys improved mechanical [1-3] and chemical properties of metals. Zn-Ni alloy deposits on iron increases strongly the corrosion resistance $[2,3]$.

The electrodeposition of $\mathrm{Zn}-\mathrm{Ni}$ alloys is classified by Brenner [4] as an anomalous codeposition, where zinc, which is the less noble metal, is preferentially deposited. Although this phenomenon has been known since 1907, the codeposition mechanisms of zinc and nickel are not well understood.

Several studies were carried out to explain this behaviour [5] in contradiction with the thermodynamic.

The nature of the anomalous codeposition has been extensively investigated, and one of the explanations is the formation of the hydroxide precipitate of the less noble metal at the cathode. The hydroxide is caused by a local increase of $\mathrm{pH}$. This precipitate may suppress deposition of the noble metal [6]. It was noticed that anomalous codeposition occurred even at low current densities [7], where hydrogen formation is unable to cause large alkanization effects. Another explanation is based on the underpotential (UDP) of zinc on nickel-rich zinc alloys or on nickel nuclei [8]. Matlosz [9] uses a two-step reaction mechanism involving adsorbed monovalent intermediate ions for both electrodeposition of iron and nickel, as a single metal, and combines the two to develop a model for codeposition. Anomalous effects are assumed to be caused by preferential surface coverage due to differences in tafel rate constants for electrodeposition.

Many studies were carried out to attempt minimizing the inhibition phenomenon. Ashassi et al. [10] used a pulsed current in order to decrease zinc hydroxide formation at the cathodic surface. They consider that anomalous codeposition is due to the slow kinetic of nickel on steel. Hu and Bai [11] showed the possibility to obtain a composition of the deposit equal to that of the solution by the use of cyclic voltammetry. From Zhou and JO'Keefe work [12], the anomalous codeposition can be reduced by adding additives as tin.

It has been reported that the deposition of nickel needs low overpotential to create the initial nucleus [13] and the deposit grows at low potentials.

It has been noticed that normal codeposition takes place at low current density. Boric acid and some other reactive have the ability to decrease the current density. According to Karwas and Hepel [14] boric acid inhibits zinc deposition shifting the nickel content in alloys toward Ni-rich phases. 
From Šupicová and all work [15], boric acid shifts the reduction peak to more negative potentials and increases the peak height. It improves morphology and brightness, as well as the adhesion of the deposited Ni. In addition it acts as a catalyst lowering the overvoltage which allows the deposit of nickel instead of $\mathrm{H}_{2}$. For Hoare [16], boric acid plays a more important role than that of a buffer. Boric acid forms a complex from which nickel can be discharged more easily.

The present work focuses on the study of the $\mathrm{Zn}-\mathrm{Ni}$ alloy electrodeposition in sodium sulfate baths in presence of boric acid and cadmium. In order to identify the effect of boric acid on current density, polarizations curves were plotted with various boric acid concentrations. The nucleation potential was studied in the presence of boric acid. The behaviour of cadmium on the zinc-nickel deposition was investigated.

\section{Experimental}

All experiments were carried out in a three-electrode cell with a capacity of $250 \mathrm{~mL}$. A stainless-steel electrode with a surface of $2 \mathrm{~cm}^{2}$ as a working electrode, a titanium grid coated with ruthenium oxide $\left(\mathrm{Ti} / \mathrm{RuO}_{2}\right)$ as a counter electrode, and an electrode of calomel saturated (ECS) as a reference electrode $\left(\mathrm{Hg}_{2} \mathrm{Cl}_{2} / \mathrm{Hg}\right)$. The reference electrode was immersed in the upper section of a luggin capillary, and its end was placed as close as possible to the working electrode to minimize errors due to ohmic drop in the electrolytes. The counter electrode was placed in parallel with the working electrode at a distance of $2 \mathrm{~cm}$. Potentiodynamic polarization curves were measured at a scan of $5 \mathrm{mV} / \mathrm{s}$ starting from open circuit with a potentiostat (Radiometer analytical PGP201) assisted by a VoltaMster 4 software.

All solutions were freshly prepared with analytical grade chemicals (Merck) and distilled water. The electrolyte for the alloy deposition was a solution of $0.5 \mathrm{M}$ sodium sulfate. The $\mathrm{Zn}-\mathrm{Ni}$ alloys deposits were obtained at room temperature from electrolyte containing $0.02 \mathrm{M}$ of $\mathrm{ZnSO}_{4} \cdot 7 \mathrm{H}_{2} \mathrm{O}$ and $0.02 \mathrm{M}$ of $\mathrm{NiSO}_{4} \cdot 6 \mathrm{H}_{2} \mathrm{O}$.

The working electrode was polished with abrasive paper (\#320, \#1200 and \#2000 SiC) and finished with polishing slurry of $0.5 \mu \mathrm{m} \mathrm{Al}_{2} \mathrm{O}_{3}$ powder followed by washing with distilled water then with acetone and finally dried under warm airflow.

Before each experiment, the solution was purified with pure nitrogen for $10 \mathrm{mn}$ to release oxygen dissolved and maintained under nitrogen atmosphere during the run of experiments.

The temperature was kept constant at $25^{\circ} \mathrm{C}$ by using a water-jacketed cell. The solution was agitated with a mechanical stirrer in order to have uniform bulk $\mathrm{pH}$. The rotational speed of the stirrer was kept at $250 \mathrm{rpm}$ for all experiments.

After deposition, the electrode is removed from the solution rinsed with distilled water and then dried.

In order to determine the alloy composition, the working electrode was immersed in concentrated nitric acid to remove the deposits obtained.

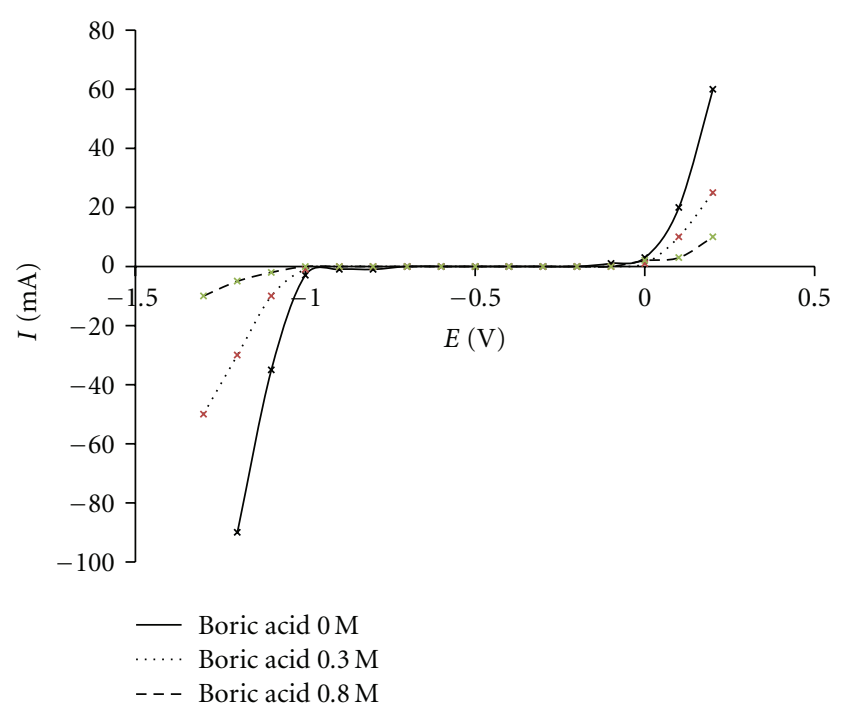

FIgURE 1: Polarization curves of $0.5 \mathrm{M}$ sodium sulfate solution for different concentrations of boric acid.

The surface morphology of the deposit was analysed using scanning electron microscopy (JSM-5500LV, SEM, Japan).

The composition of the deposits was determined using atomic absorption spectrophotometry (PERKIN-ELMER, AA 5000). Deposition current efficiency was calculated for each deposit using electrochemical equivalents of $\mathrm{Ni}$ (II) and Zn (II).

\section{Results and Discussions}

3.1. Effect of Boric Acid on the Polarization and Potential Curves. Figure 1 shows the effect of boric acid on the polarization curves of a solution containing $0.5 \mathrm{M}$ of sodium sulfat. The measured current density decreases with increasing boric acid concentration suggesting that boric acid inhibits protons reduction that is extended to more negative potentials. This effect is attributed to adsorption of boric acid species on the substrate.

Figure 2 shows the influence of boric acid on the curves potential - time during the deposition of zinc-nickel alloy on steel at constant current density. The nucleation potential and the nucleation time are where a sudden change in the slope occurs. This sudden change in the slope is an indication of diffusion controlled reduction system. In the presence of boric acid the nucleation potential decreases and nucleation time increases. Therefore, in the presence of boric acid the nucleation time increases and the nucleation potential shifts to positive values. Thus boric acid by reducing nucleation potential leads to reduce anomalous deposition and hydrogen evolution reaction.

3.2. Effect of Cadmium on Zinc and Nickel Deposition. Figure 3 shows the effect of cadmium on the deposition of zinc. With a concentration ten-times smaller than that of zinc, the presence of cadmium decreases the deposition of 


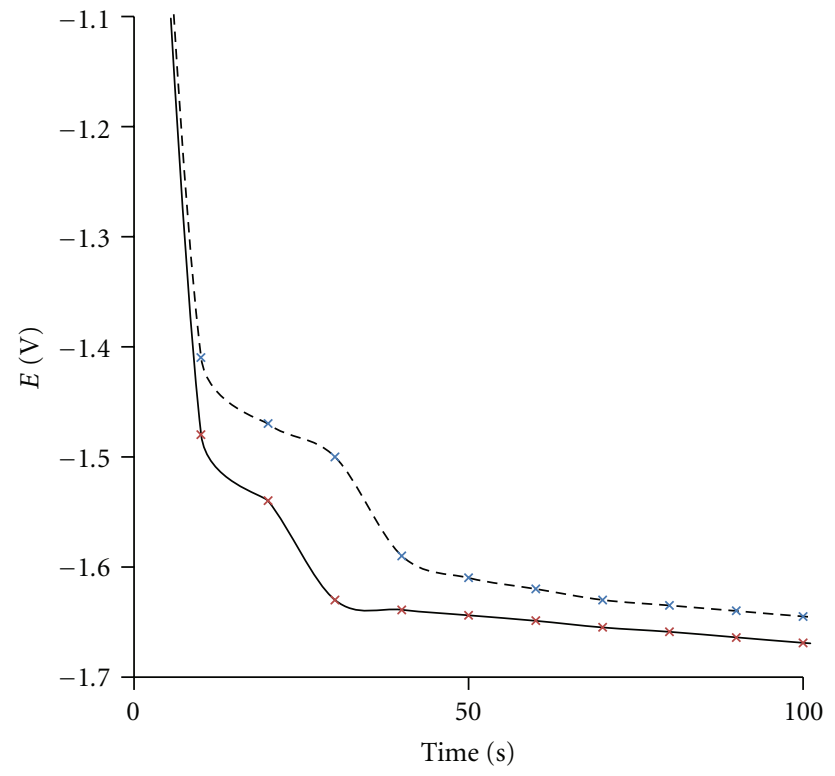

- Boric acid $0 \mathrm{M}$

- - Boric acid $0.8 \mathrm{M}$

FIgURE 2: Chronopotentiometric curves at $5 \mathrm{~mA} / \mathrm{cm}^{2}$ on steel electrode.

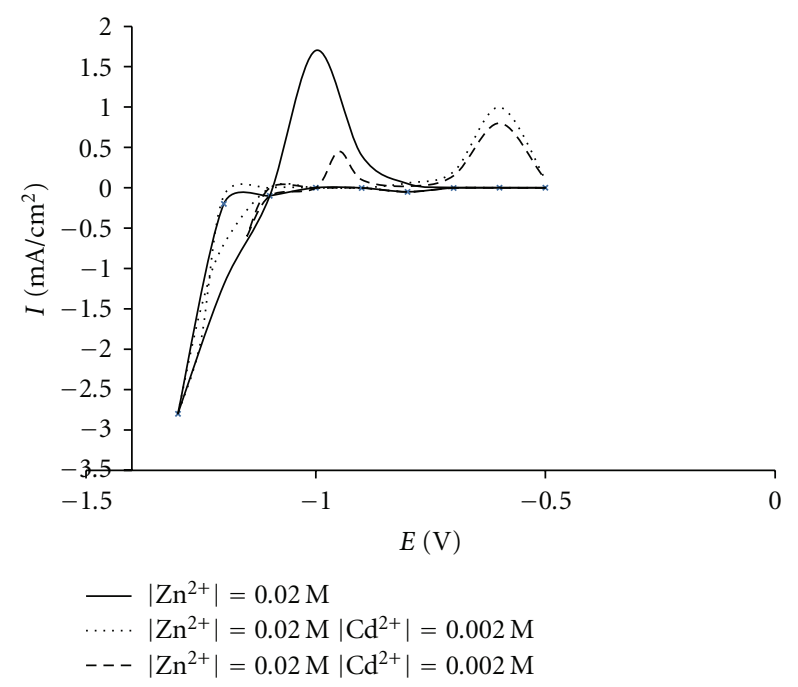

FIgURE 3: Cyclic voltammetry at a scan of $5 \mathrm{mV} / \mathrm{s}$ of a metallic solution containing $\left|\mathrm{Na}_{2} \mathrm{SO}_{4}\right|=0.5 \mathrm{M}$ at $\mathrm{pH}=3.5$.

zinc. Moreover in the presence of cadmium, the deposition of zinc is suppressed when the cathodic potential sweep is reversed at $-1.2 \mathrm{~V}$ represented by dotted lines in the voltammogram.

In Figure 4, cyclic voltammograms behavior of steel in the bath solutions were represented. As for the previous figure, the peak observed at $-0.95 \mathrm{~V} / \mathrm{SCE}$ disappears in the presence of cadmium indicating that it concerns the zinc. Many authors attribute this peak to the formation of $\delta$-phase

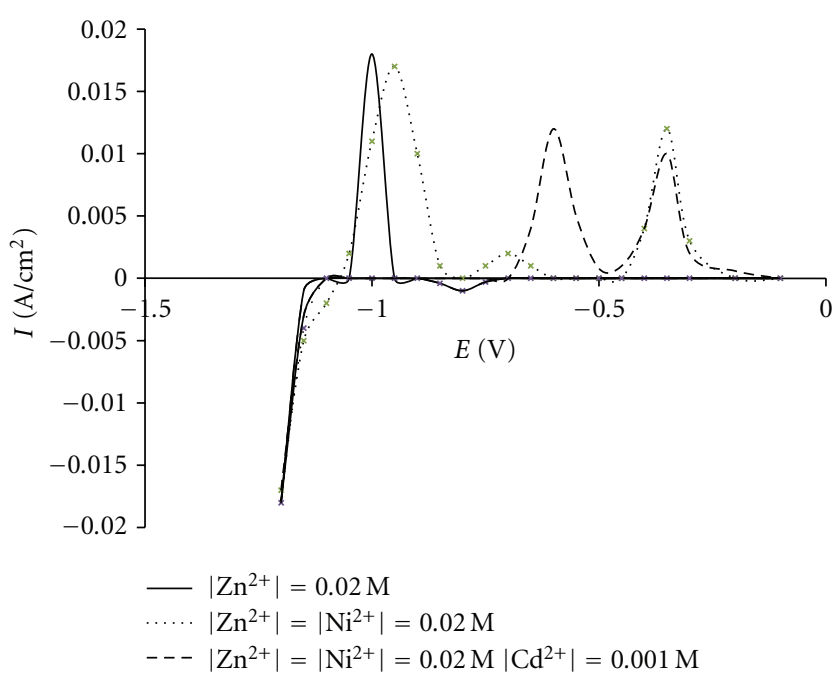

FIGURE 4: Cyclic voltammograms at a scan rate $5 \mathrm{mV} / \mathrm{s}$ of a metallic solution containing $\left|\mathrm{Na}_{2} \mathrm{SO}_{4}\right|=0.5 \mathrm{M}$ at $\mathrm{pH}=3.5$.

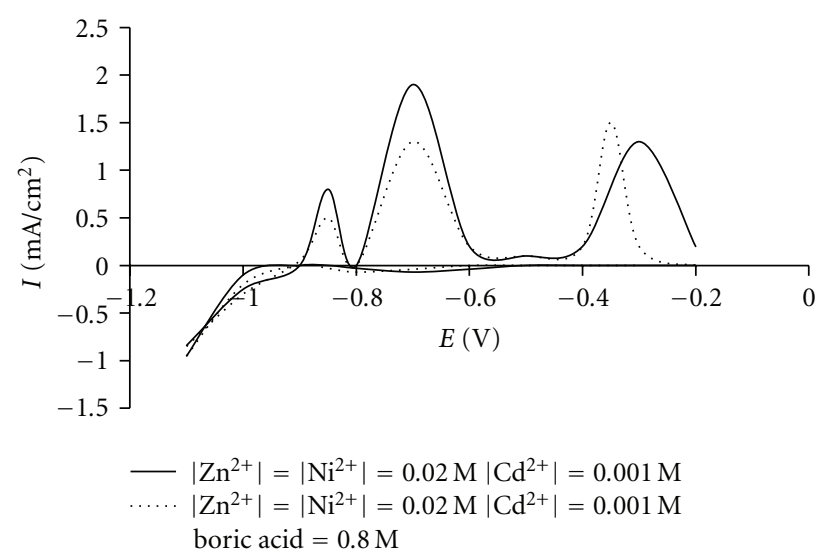

Figure 5: Cyclic voltammetry at a scan of $5 \mathrm{mV} / \mathrm{s}$ of a metallic solution containing $\left|\mathrm{Na}_{2} \mathrm{SO}_{4}\right|=0.5 \mathrm{M}$ at $\mathrm{pH}=3.5$.

$\left(\mathrm{Ni}_{3} \mathrm{Zn}_{22}\right)$. This observation confirms that zinc is inhibited by cadmium regardless of the form in which it appears.

We can notice, on the other hand, that cadmium has no effect on the nickel deposit.

3.3. Combined Effect of Boric Acid and Cadmium on ZincNickel Deposition. Figure 5 shows the combined effect of boric acid and cadmium on the deposition of zinc and nickel. As mentioned above, cadmium has a strong effect on the zinc deposit. It reduces zinc deposition. The presence of boric acid decreases the zinc deposit while it shifts the reduction peak of nickel to more negative potentials and increases the peak height.

Boric acid has an effect on the cadmium deposition since the intensity of the anodic stripping decreases.

The effect of the presence of $\mathrm{Cd}^{2+}$ on the electrodeposition of nickel can be seen from Figure 6. The current remained unchanged when the concentration of $\mathrm{Cd}^{2+}$ is 


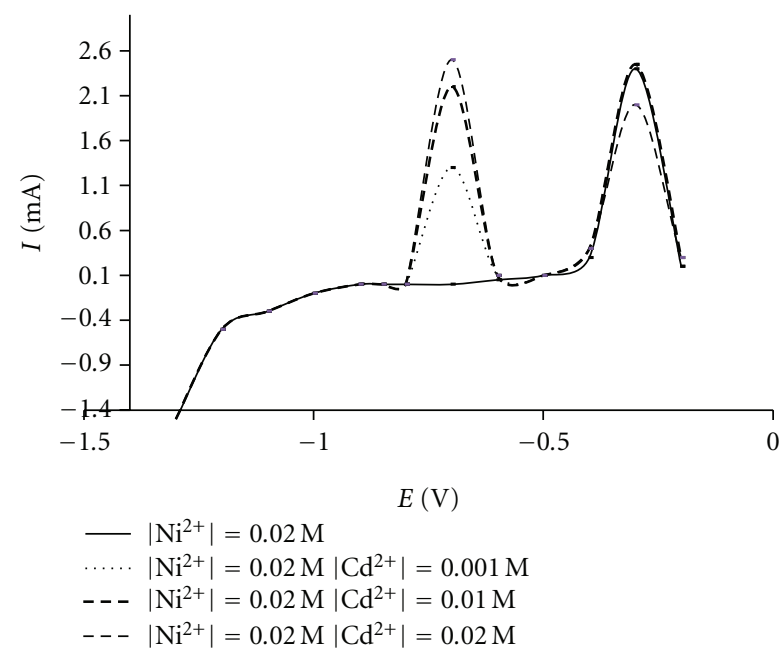

FIgURE 6: Anodic stripping voltammetry at a scan of $5 \mathrm{mV} / \mathrm{s}$ of a metallic solution containing $\left|\mathrm{Na}_{2} \mathrm{SO}_{4}\right|=0.5 \mathrm{M}\left|\mathrm{H}_{3} \mathrm{BO}_{3}\right|=0.8 \mathrm{M}$ at $\mathrm{pH}=3.5$.

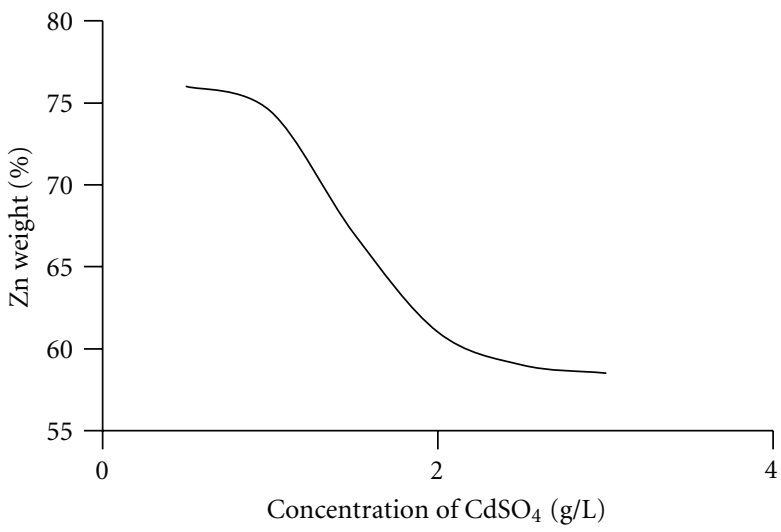

(a)

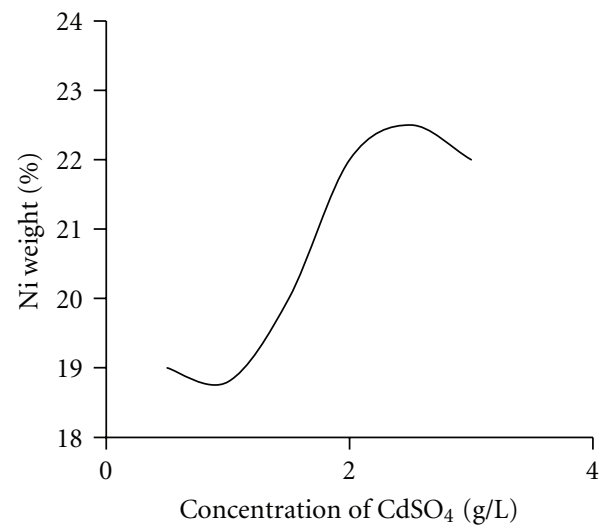

(b)

FIgURE 7: Effect of cadmium concentration on (a) $\mathrm{Zn}$ and (b) Ni at $4 \mathrm{~mA} / \mathrm{cm}^{2}$.

lower than $0.02 \mathrm{M}$. At $0.02 \mathrm{M}$ the current of redissolution of nickel decreases and the decrease may be attributed to the adsorption of cadmium [17], which blocks the active sites of the cathode surface and inhibits electrocrystallisation of nickel.

Figure 7 illustrates the influence of cadmium on nickel and zinc in the deposit.

At $4 \mathrm{~mA} / \mathrm{cm}^{2}$ the increases of cadmium in the bath decreases the zinc content and not nickel content. The zinc content decreased from $77 \%$ to $57 \%$ while the cadmium was increased from 0.5 to $3 \mathrm{~g} / \mathrm{L}$. The figure also shows that the composition can be easily controlled when, lower amount of cadmium $(0.5$ and $1 \mathrm{~g} / \mathrm{L})$ is introduced in the bath.

Figure 8 show, the effect of amount of cadmium sulfat on the morphology of final deposits at a current density of $4 \mathrm{~mA} / \mathrm{cm}^{2}$. When cadmium sulfat concentration is below $2 \mathrm{~g} / \mathrm{L}$, a smooth and uniform deposition can be obtained. Above $2 \mathrm{~g} / \mathrm{L}$ of sulfat cadmium leads to a non-uniform surface with higher cadmium content on the surface.
A comparison of the optical micrographs in Figure 9 shows a remarkably refined $\mathrm{Zn}-\mathrm{Ni}$ coating structure in the presence of boric acid. Coating in the presence of boric acid looked compact, bright, and smooth.

Figure 10 shows the effect of boric acid on the surface morphology of $\mathrm{Zn}-\mathrm{Ni}$ alloy deposits in the presence of cadmium and cadmium boric acid. In the presence of cadmium boric acid smaller particles in the range of 1-2 $\mu \mathrm{m}$ are observed. The decrease of particles in presence of boric is due to the preferred homogeneous nickel deposit that occurs at lower current densities. Boric acid acts on lowering current density.

The current efficiency is plotted with the molar ratio $\left|\mathrm{Zn}^{2+}\right| /\left|\mathrm{Ni}^{2+}\right|$ in the Figure 11.

The increase of the current efficiency, for the ratio between $0<\left|\mathrm{Zn}^{2+}\right| /\left|\mathrm{Ni}^{2+}\right|<1$, results in the strong reduction of nickel. The increase is more important for baths containing boric acid and boric acid-cadmium than for those without boric acid. This observation confirms that boric acid increases the percentage of nickel in the deposit and 


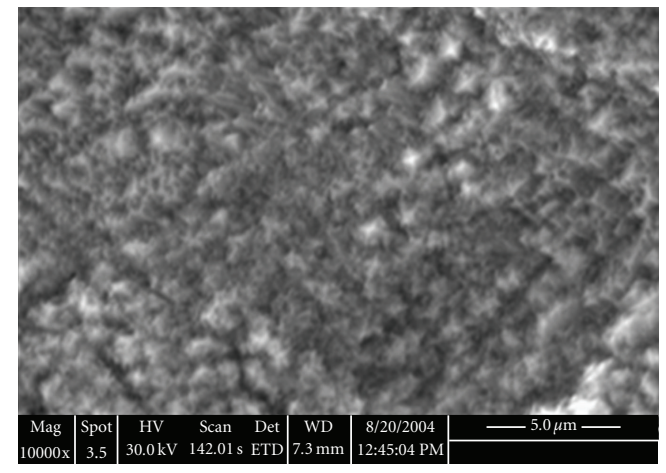

(a)

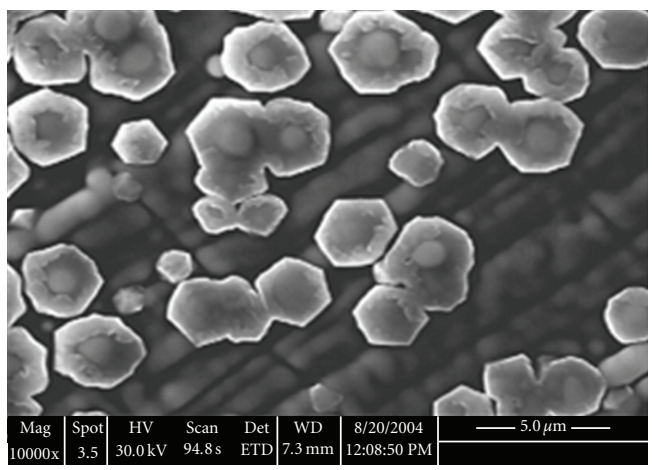

(b)

FIGURE 8: SEM photographs of electrodeposition of $\mathrm{Zn}-\mathrm{Ni}$ on steel at $4 \mathrm{~mA} / \mathrm{cm}^{2}$. (a) $\left|\mathrm{CdSO}_{4}\right|=1.5 \mathrm{~g} / \mathrm{L},(\mathrm{b})\left|\mathrm{CdSO} \mathrm{S}_{4}\right|=2.5 \mathrm{~g} / \mathrm{L}$.

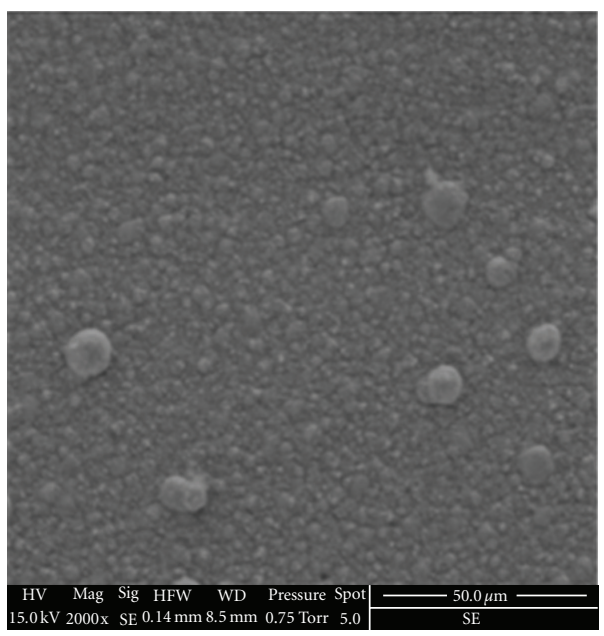

(a)

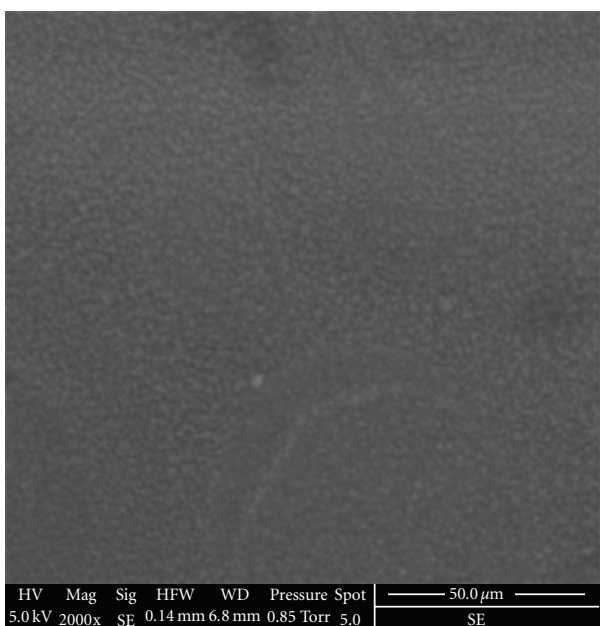

(b)

FIgURE 9: SEM Zn-Ni electrodeposited on steel at $4 \mathrm{~mA} / \mathrm{cm}^{2}$ from a bath containing $0.02 \mathrm{M} \mathrm{ZnSO}_{4}, 0.02 \mathrm{M} \mathrm{NiSO}_{4}$, and $0.5 \mathrm{M} \mathrm{Na}_{2} \mathrm{SO}_{4}$. (a) Without boric acid, (b) $\left|\mathrm{H}_{3} \mathrm{BO}_{3}\right|=0.8 \mathrm{M}$.

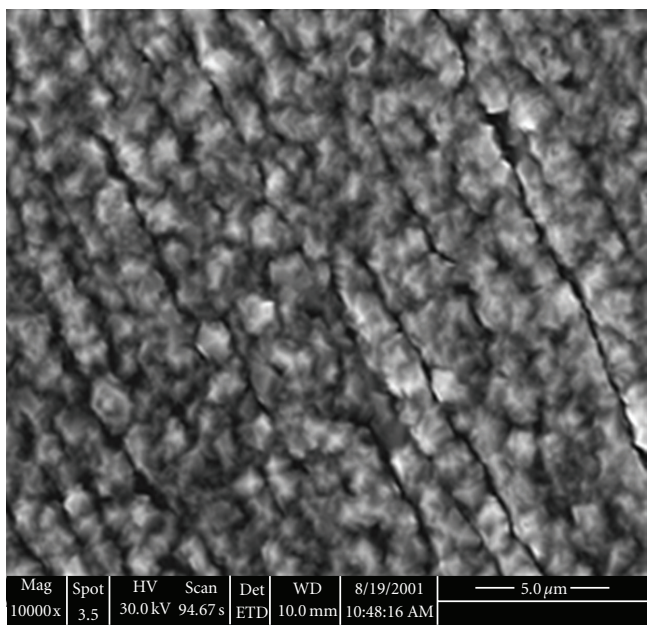

(a)

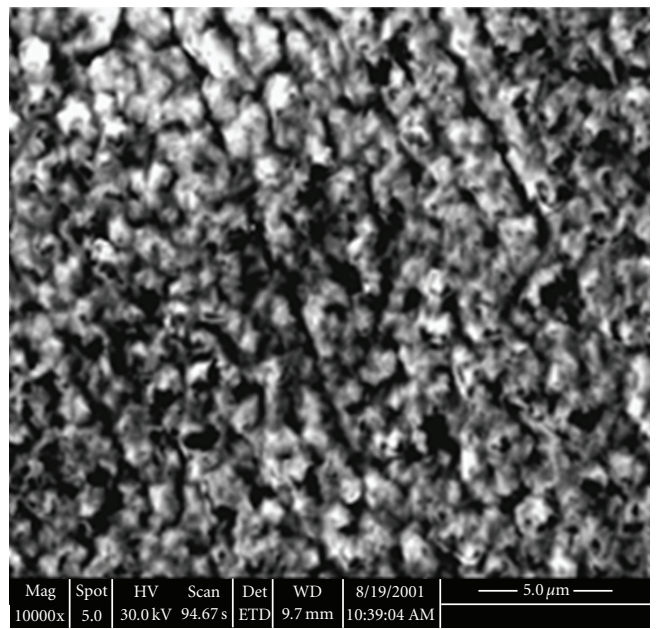

(b)

Figure 10: SEM Zn-Ni electrodeposited on steel at $4 \mathrm{~mA} / \mathrm{cm}^{2}$ from a bath containing $0.02 \mathrm{M} \mathrm{ZnSO}_{4}, 0.02 \mathrm{M} \mathrm{NiSO}_{4}$, and $0.5 \mathrm{M} \mathrm{Na}_{2} \mathrm{SO}_{4}$. (a) $\left|\mathrm{Cd}^{2+}\right|=0.001 \mathrm{M}$, (b) $\left|\mathrm{Cd}^{2+}\right|=0.001 \mathrm{M}$ boric acid $=0.8 \mathrm{M}$. 


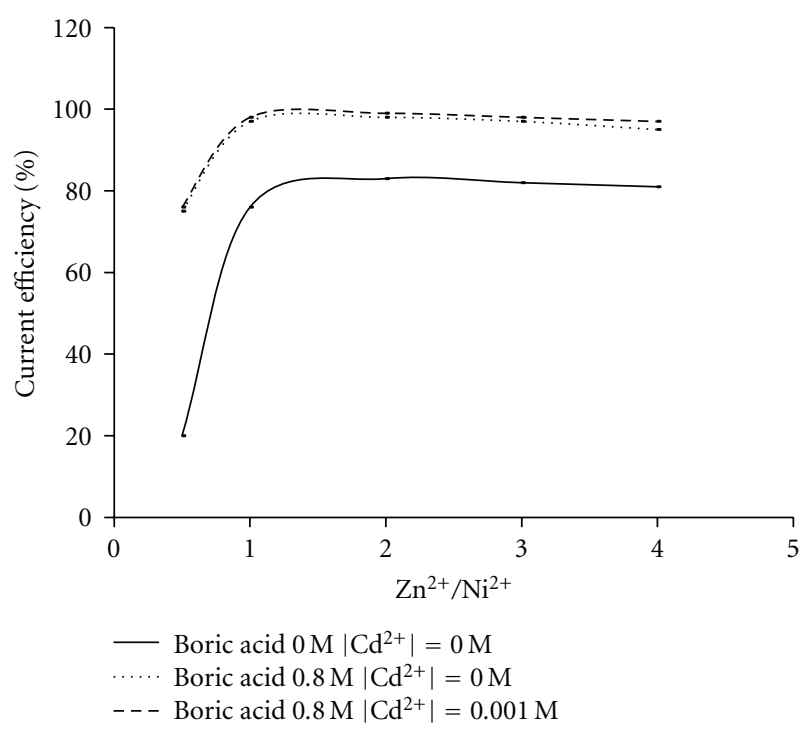

Figure 11: Current efficiency on the molar ratio plotted at $5 \mathrm{~mA} / \mathrm{cm}^{2}$ in a solution containing $\left|\mathrm{Na}_{2} \mathrm{SO}_{4}\right|=0.5 \mathrm{M}$.

inhibits the deposition of zinc and protons discharge. Boric acid would be expected to influence reactions that take place at the electrode surface as hydrogen evolution, zinc, and nickel deposition. According to Karwas and Hepel [14], boric acid suppresses the secondary nucleation while it increases the primary nucleation density. However, cadmium has no effect on the current efficiency. For $\left|\mathrm{Zn}^{2+}\right| /\left|\mathrm{Ni}^{2+}\right|$ ratio values greater than 1 the current efficiency is slightly dependent on the changes in the $\left|\mathrm{Zn}^{2+}\right| /\left|\mathrm{Ni}^{2+}\right|$ ratio. For $\left|\mathrm{Zn}^{2+}\right| /\left|\mathrm{Ni}^{2+}\right|$ ratio values higher than 2 , the percentage of nickel in the deposit slightly decreases. This diminution is attributed to the weak rate of hydrogen reaction on the cathodic surface recovered with zinc compared to the one observed on bare steel for example [18].

\section{Conclusion}

The electrodeposition of $\mathrm{Zn}-\mathrm{Ni}$ alloys is anomalous when the percentage of nickel in the deposit is lower than that in the solution. Boric acid extends the proton discharge potential to more cathodic values. It shifts the reduction peak to more negative potentials, and increases the peak height. Boric acid enhances the Ni nucleation process, and improved deposition of Ni consequently decreases anomalous deposition.

Cadmium decreases strongly the deposition of zinc but has no effect on nickel. As shown in the morphology of $\mathrm{Zn}-\mathrm{Ni}$-Cd with varying $\mathrm{CdSO}_{4}$ concentration well-defined particles are seen up to $2 \mathrm{~g} / \mathrm{L}$ of $\mathrm{CdSO}_{4}$ and nonuniform surface was obtained beyond $2 \mathrm{~g} / \mathrm{L}$.

For a ratio $\left|\mathrm{Zn}^{2+}\right| /\left|\mathrm{Ni}^{2+}\right|=0.5$, and in the presence of cadmium-boric acid at a concentration of $0.8 \mathrm{M}$ the codeposition tends toward normal deposition since the point on the curve corresponding to the ratio 0.5 is almost coincident with that on the curve CRL. Boric acid enhances the current efficiency while cadmium has no effect on current efficiency.

\section{References}

[1] Y. P. Lin and J. R. Selman, "Electrodeposition of corrosionresistant Ni-Zn alloy. I.Cyclic voltammetric study," Journal of the Electrochemical Society, vol. 140, no. 5, pp. 1299-1303, 1993.

[2] Y. Miyoshi, "State of the art in precoated steel sheet for automotive body materials in Japan," ISIJ International, vol. 31, no. 1, pp. 1-10, 1991.

[3] S. Wakano, A. Shibuya, Y. Hobo, and M. Nishihara, "Corrosion Performance of $\mathrm{Zn}$ alloy Precoated Steels for Automotive Body," ISIJ International, vol. 18, p. 967, 1983.

[4] A. Brenner, Electrodeposition of Alloys: Principles and Practice, vol. 1-2, Academic Press, New York, NY, USA, 1963.

[5] B. C. Baker and A. C. West, "Electrochemical impedance spectroscopy study of nickel-iron deposition II. Theoretical interpretation," Journal of the Electrochemical Society, vol. 144, no. 1, pp. 169-175, 1997.

[6] H. Fukushima, T. Akiyama, and K. Higashi, "Electrodeposition behavior of $\mathrm{Zn}-\mathrm{Ni}$ alloys from sulfate baths over a wide range of current density," Metallurgy, vol. 42, no. 3, pp. 242247, 1988.

[7] J. Horkans, "Effect of plating parameters on electrodeposited NiFe," Journal of the Electrochemical Society, vol. 128, no. 1, pp. 45-49, 1981.

[8] M. J. Nicol and H. I. Philip, "Underpotential deposition and its relation to the anomalous deposition of metals in alloys," Journal of Electroanalytical Chemistry, vol. 70, no. 2, pp. 233237, 1976.

[9] M. Matlosz, "Competitive adsorption effects in the electrodeposition in iron-nickel alloys," Journal of the Electrochemical Society, vol. 140, no. 8, pp. 2272-2279, 1993.

[10] H. Ashassi-Sorkhabi, A. Hagrah, N. Parvini-Ahmadi, and J. Manzoori, "Zinc-nickel alloy coatings electrodeposited from a chloride bath using direct and pulse current," Surface and Coatings Technology, vol. 140, no. 3, pp. 278-283, 2001.

[11] C. C. Hu and A. Bai, "The inhibition of anomalous codeposition of iron-group alloys using cyclic voltammetry," Journal of the Electrochemical Society, vol. 149, no. 11, pp. C615-C622, 2002. 
[12] Z. Zhou and T. J. O'Keefe, "Modification of anomalous deposition of $\mathrm{Zn}-\mathrm{Ni}$ alloy by using tin additions," Surface and Coatings Technology, vol. 96, no. 169, p. 191, 1997.

[13] C. Müller, M. Sarret, and M. Benballa, "Some peculiarities in the codeposition of zinc-nickel alloys," Electrochimica Acta, vol. 46, no. 18, pp. 2811-2817, 2001.

[14] C. Karwas and T. Hepel, "Morphology and composition of electrodeposited cobalt-zinc alloys and the influence of boric acid," Journal of the Electrochemical Society, vol. 136, no. 6, pp. 1672-1678, 1989.

[15] M. Šupicová, R. Rozik, L. Trnková, R. Oriňáková, and M. Gálová, "Influence of boric acid on the electrochemical deposition of Ni," Journal of Solid State Electrochemistry, vol. 10, no. 2, pp. 61-68, 2006.

[16] J. P. Hoare, "Boric acid as a catalyst in nickel plating solutions," Journal of the Electrochemical Society, vol. 134, no. 12, pp. 3102-3103, 1987.

[17] K. Kazuo, S. Takahiro, and S. Kunioa, "Morphology evolution of zinc-nickel binary alloys electrodeposited with cadmium additive," Journal of the Electrochemical Society, vol. 142, no. 10, pp. L193-L195, 1995.

[18] Z. F. Lodhi, J. M. C. Mol, A. Hovestad, H. Terryn, and J. H. W. de Wit, "Electrodeposition of Zn-Co and Zn-Co-Fe alloys from acidic chloride electrolytes," Surface and Coatings Technology, vol. 202, no. 1, pp. 84-90, 2007. 


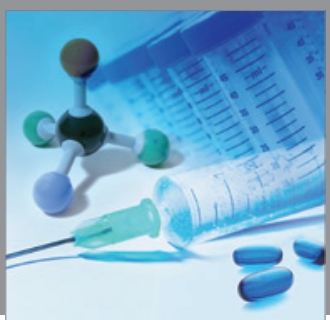

International Journal of

Medicinal Chemistry

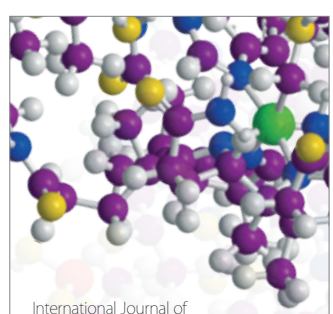

Carbohydrate Chemistry

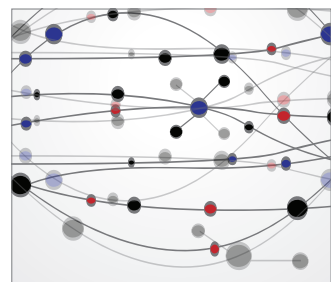

The Scientific World Journal
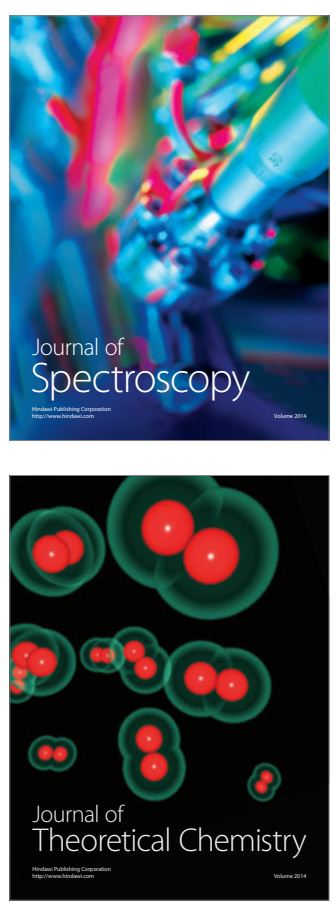
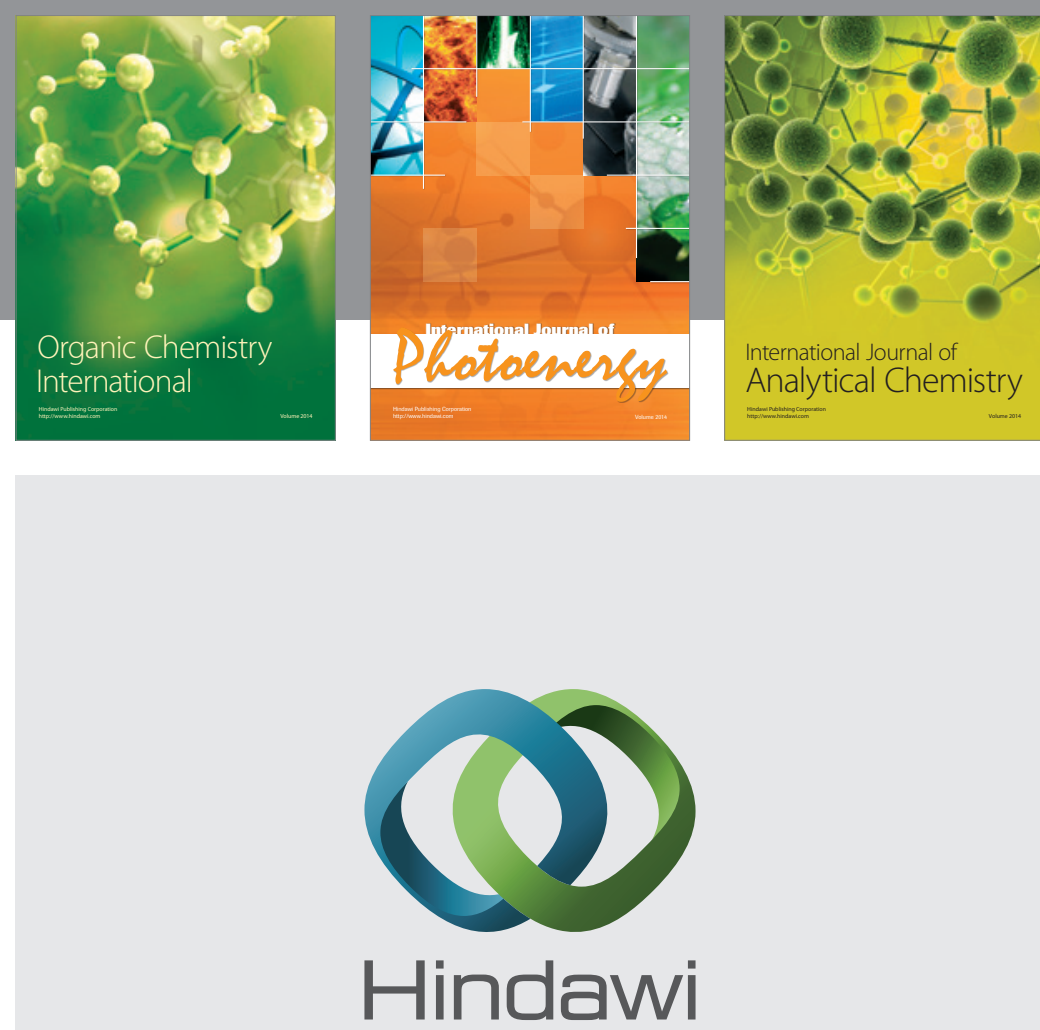

Submit your manuscripts at

http://www.hindawi.com
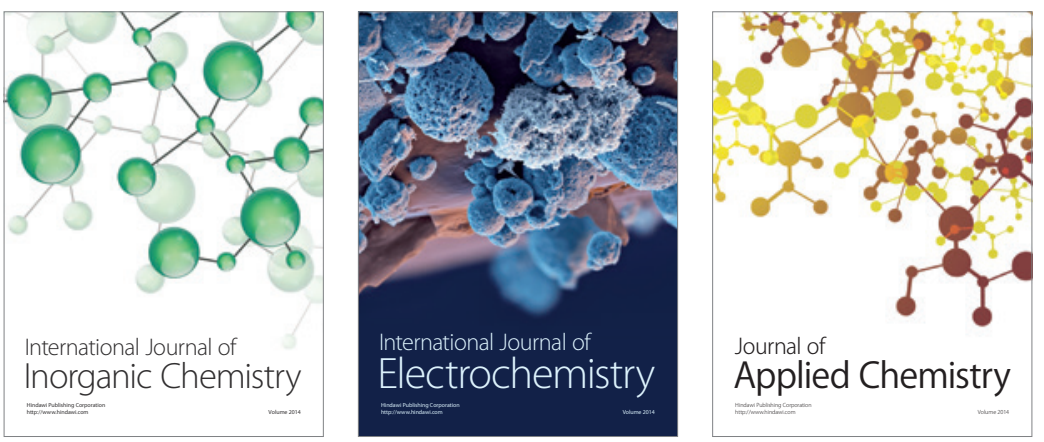

Journal of

Applied Chemistry
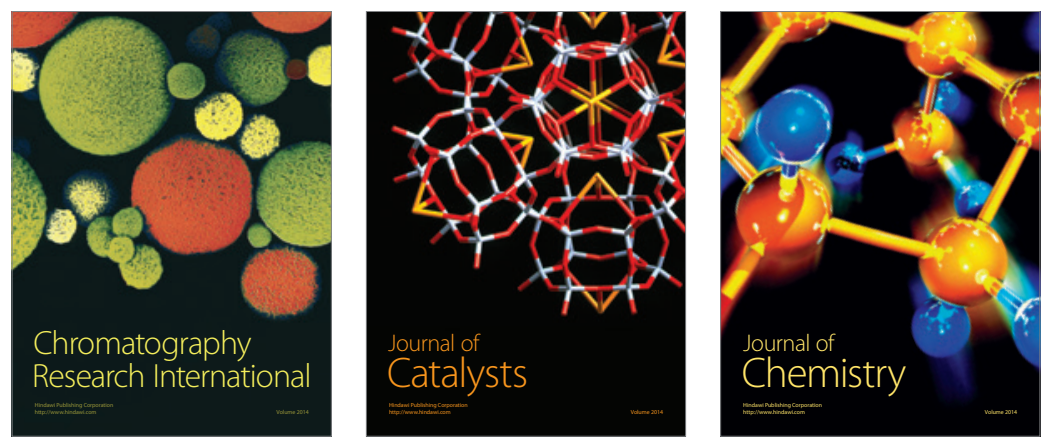
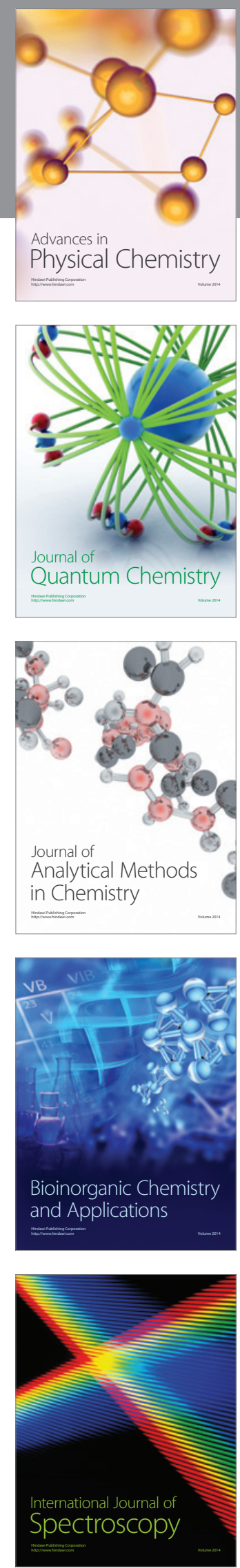